\title{
MAGNETOESTRATIGRAFIA E ANÁLISE ESPECTRAL DE RITMITOS PERMOCARBONÍFEROS DA BACIA DO PARANÁ: INFLUÊNCIAS DOS CICLOS ORBITAIS NO REGIME DEPOSICIONAL
}

\author{
Daniel Ribeiro Franco \\ Orientador: Dra. Marcia Ernesto (IAG-USP) \\ 192 p. - Tese (Doutorado) - Defesa 06.06.2007
}

RESUMO. Este trabalho teve por objetivo investigar a escala temporal envolvida na deposição de ritmitos permocarboníferos da Bacia do Paraná (Subgrupo Itararé), expostos no Parque do Varvito (Itu, SP) e pedreira Itaú (Trombudo Central, SC), através de dados paleomagnéticos e de anisotropia de suscetibilidade magnética. Os estudos paleomagnéticos revelaram componentes de magnetização estável para ambas as coleções, com indicações de que a magnetização remanente é devida a portadores magnéticos (principalmente magnetita e hematita) de origem detrítica. A componente de magnetização característica, em ambos os caso é de polaridade reversa, e foi identificada nos dois portadores magnéticos principais. A investigação da mineralogia magnética foi feita através de várias técnicas, incluindo espectroscopia Mössbauer, curvas termomagnéticas, curvas de histerese e ZFC/FC, além de microscopia ótica e eletrônica. Os dados paleomagnéticos e de anisotropia de susceptibilidade magnética permitiram a composição de séries temporais, que foram submetidas à análise espectral por transformada de Fourier de Lomb-Scargle para séries desigualmente espaçadas. Os espectros de potência resultantes foram posteriormente comparados com os espectros de séries de espessura individual das unidades litológicas, o que possibilitou a investigação de sinais harmônicos, sobre a qual foram propostas inferências a respeito das escalas temporais de sedimentação. Esta etapa do trabalho revelou escalas milenares para o domínio do tempo nos espectros de potência, indicando o registro dos ciclos orbitais de Milankovitch, bem como quase-periodicidades associadas à variabilidade solar e feedback do sistema oceânico-atmosférico, para todas as análises. Este conjunto de dados sugere o caráter não anual de deposição dos ritmitos, ao contrário do proposto por alguns autores. 0 pólo paleomagnético calculado para a seção de Rio do Sul é compatível com o pólo do Permocarbonífero para a Bacia Sanfranciscana (MG), indicando que o intervalo de tempo envolvido na deposição dos sedimentos é suficientemente longo para eliminar os efeitos da variação secular do campo geomagnético. Alguns resultados adicionais desta tese proveram informações especiais: (i) Foram observados ciclos de indução solar (ciclos de Hallstattzein e de Suess) e a sugestão de ciclo compatível com o ciclo glacial-interglacial de Bond, recentemente sugerido como de origem solar, o que apontaria para uma possível feição harmônica, dominante sobre o sistema oceânico-atmosférico, e que poderia operar sobre períodos geológicos mais antigos; (ii) registro da remanência magnética possivelmente controlado por fatores mecânicos na sucessão de Itu, provavelmente relacionados a correntes de turbidez; (iii) indícios da presença de magnetossomas possivelmente rompidas e/ou oxidadas, em especial para a sucessão de ltu.

ABSTRACT. This work aimed to investigate the timescale of the sedimentation of Permocarboniferous rhythmites from Paraná Basin (Itararé Subgroup) cropping out at the Parque do Varvito (Itu, SP), and at the Itaú quarry (Trombudo Central, SC) by means of paleomagnetic and anisotropy of magnetic susceptibility (ASM). The paleomagnetic study revealed stable magnetization components for both sections, which are carried by magnetic magnetite and hematite of detritic origin. The characteristic magnetization direction for each section is of reversed polarity and is found in both magnetite and hematite. Several techniques were used for investigating the magnetic mineralogy including Mössbauer spectrometry, thermomagnetic curves, hysteresis and ZFC/FC curves, optical and electronic microscopy. The paleomagnetic and ASM data allowed the assembly of time series that were submitted to spectral analysis by the Lomb-Scargle Fourier transform for unevenly spaced series. The resulting power spectra were then compared with the thickness spectrum and submitted to an astronomical calibration, which followed theoretical spectral peak ratios predicted for Permian times. Based on the harmonic signals identified in all time series it was possible to infer deposition rates for both Itu and Itaú rhythmites. This procedure pointed to millennial timescale, and periodical signal compatible to Milankovitch orbital forcing, as well as quasi-periodicities related to solar variability and feedback of ocean-atmospheric system, were identified in both sections. Such evidences are remarkably indicative for a non-annual sedimentation character, in opposition to the previous hypothesis. The paleomagnetic data from the Rio do Sul rocks allowed the calculation of a paleomagnetic pole which is in agreement to the one recently obtained for the Santa Fé Group, Sanfranciscana Basin (MG), indicating that the time interval comprised by the Rio do Sul rhythmites is long enough for eliminating the secular variation effects. Results from this work provide also indications for the record of (i) solar forcing cycles (Hallstattzein and Suess cycles); (ii) spectral peak values of $1.5 \mathrm{ky}$ and $6.0-8.0 \mathrm{ky}$ cycle, which is compatible to the glacial-interglacial Bond cycle observed in Quaternary geological records. Such result would extend to ancient times the atmosphere-ocean interaction pattern; (iii) indicative data pointing out to the possibility of magnetic biomineralization with disrupted or oxidized mineral chains, especially for IT section, which still demands further investigation. 